\title{
Optimasi Klasifikasi Parasit Malaria Dengan Metode LVQ, SVM dan Backpropagation
}

\author{
Jani Kusanti ${ }^{*}$, Tri Irianto Tjendrowarsono ${ }^{2}$ \\ ${ }^{1}$ Program Studi Teknik Informatika, Universitas Surakarta \\ ${ }^{2}$ Program Studi Teknik Elektro, Universitas Surakarta \\ 1,2Jln. Raya Palur Km.5 Surakarta, 57772, Indonesia \\ E-mail: jani_kusanti@yahoo.com ${ }^{1}$, tri_irianto@yahoo.com²
}

\begin{tabular}{|c|c|}
\hline & Abstrak \\
\hline $\begin{array}{l}\text { Info Naskah: } \\
\text { Naskah masuk: } 28 \text { November } 2020 \\
\text { Direvisi: } 15 \text { Maret } 2021 \\
\text { Diterima: } 20 \text { Maret } 2021\end{array}$ & 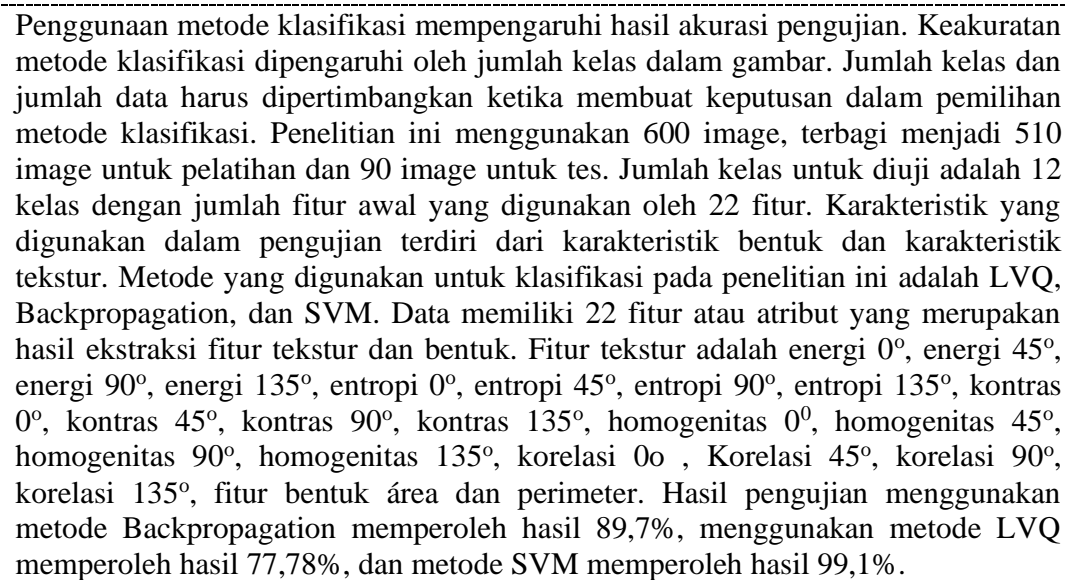 \\
\hline
\end{tabular}

\section{Keywords:}

LVQ;

SVM;

Backpropagation;

Malaria.

\begin{abstract}
The use of the classification method affects the results of the accuracy of the test. The accuracy of the classification method is affected by the number of classes in the image. The number of classes and the amount of data should be considered when making decisions in choosing a classification method. This study used 600 images, divided into 510 images for training and 90 images for testing. The number of classes to be tested is 12 classes with the initial number of features used by 22 features. The characteristics used in the test consist of shape characteristics and texture characteristics. The methods used for classification in this study are LVQ, Backpropagation, and SVM. The data has 22 features or attributes that are the result of texture and shape feature extraction. Texture features are energy $0^{\circ}$, energy $45^{\circ}$, energy $90^{\circ}$, energy $135^{\circ}$, entropy $0^{\circ}$, entropy $45^{\circ}$, entropy $90^{\circ}$, entropy $135^{\circ}$, contrast $0^{\circ}$, contrast $45^{\circ}$, contrast $90^{\circ}$, contrast $135^{\circ}$, homogeneity $0^{\circ}$, homogeneity $45^{\circ}$, homogeneity $90^{\circ}$, homogeneity $135^{\circ}$, correlation $0^{\circ}$, Correlation $45^{\circ}$, correlation $90^{\circ}$, correlation $135^{\circ}$, features of área and perimeter shape. The test results using the Backpropagation method obtained $89.7 \%$ results, using the LVQ method obtained $77.78 \%$ results, and the SVM method obtained $99.1 \%$ results.
\end{abstract}




\section{Pendahuluan}

Covid-19 saat ini menjadi topik utama dalam setiap percakapan dan penelitian, karena dampaknya yang luar biasa di seluruh dunia. Begitu juga dengan malaria [1] berdasarkan laporan dari Organisasi Kesehatan Dunia (WHO) ditahun 2016, malaria masuk didaftar 10 penyakit yang paling mematikan yang terkait dengan lingkungan. Tak terkecuali dengan Indonesia [2], Dirilis situs web Kementerian Kesehatan Republik Indonesia, 72 persen dari data, penduduk di Indonesia tinggal di daerah bebas malaria. Namun masih ada 10,7 juta orang tinggal di daerah endemis malaria menengah dan tinggi, seperti Papua, Papua Barat, dan NTT. Untuk alasan ini, menjadi penting penelitian tentang malaria terus dikembangkan.

Dalam studi parasit malaria seperti yang dilakukan [3]-[10] identifikasi dengan berbagai metode digunakan untuk hasil yang optimal, mulai dari metode ROI untuk pemrosesan gambar seperti yang sudah dilakukan [6][7][9], penggunaan skala abu-abu seperti yang sudah dilakukan [3]-[5], peregangan kontras yang juga sudah digunakan dalam penelitian [6][7][9]. Penggunaan segmentasi dengan fitur bentuk sudah dilakukan dalam penelitian [6][7][11], fitur tekstur [4][6][12][13], dan fitur warna [3][4][14]

Untuk hasil pengolahan berdasarkan kelompok atau kelas dilakukan menggunakan metode klasifikasi. Dalam penelitian yang sudah dilakukan sebelumnya oleh [4][9][11][15] metode klasifikasi SVM dipilih dan diperoleh hasil akurasi tinggi dengan rata-rata di atas $80 \%$. Beberapa penelitian yang sudah dilakukan oleh [16]-[18] untuk klasifikasi dipilih dengan metode Backpropagation, pada pengujian akurasi diperoleh tinggi dengan rata-rata di atas $80 \%$. Penelitian yang dilakukan oleh [6][16][15][17][18] hasil di atas 80\% dengan metode LVQ. Namun, dari banyak penelitian yang telah dilakukan, belum diketahui apakah akan menghasilkan nilai akurasi yang sama pada objek menggunakan data, kelas, dan fitur yang sama.

Untuk alasan ini, penting dalam penelitian ini melakukan penelitian yang membandingkan metode LVQ, SVM, dan Backpropagation. Tujuannya untuk mengetahui apakah hasilnya akan sama dengan penggunaan data, kelas, dan karakteristik yang sama dan untuk mengetahui apa yang mempengaruhi hasil akurasi tinggi di setiap metode klasifikasi.

\section{Metode}

Pada Gambar 1 menunjukkan metode yang dilakukan dalam penelitian. Pada penelitian ini menggunakan data citra sediaan darah tebal, sebanyak 600 data yang terbagi menjadi 510 data latih dan 90 data uji.

\subsection{Preprocessing, Dataset, dan Penentuan Fitur}

Data yang dihasilkan merupakan data yang sudah dilabeling diambil

dari https://www.cdc.gov/dpdx/malaria/index.html Seperti ditunjukkan pada Gambar 2. Data diolah dengan tahapan, data yang diambil dari dataset yang sudah dilabeling disimpan pada drive dataset malaria, satu persatu data yang sudah dilabeling dipanggil dan dilakukan ROI. Langkah awal ini merupakan langkah yang penting dan perlu pendampingan oleh pakar ahli yaitu dokter spesialist di bidang penyakit malaria. Data hasil ROI sebanyak 600 disimpan pada drive data latih. Langkah selanjutnya dilakukan proses pelatihan yang diawali dengan proses penyamaan ukuran pada citra parasite malaria, dan diikuti proses contrast stretching.

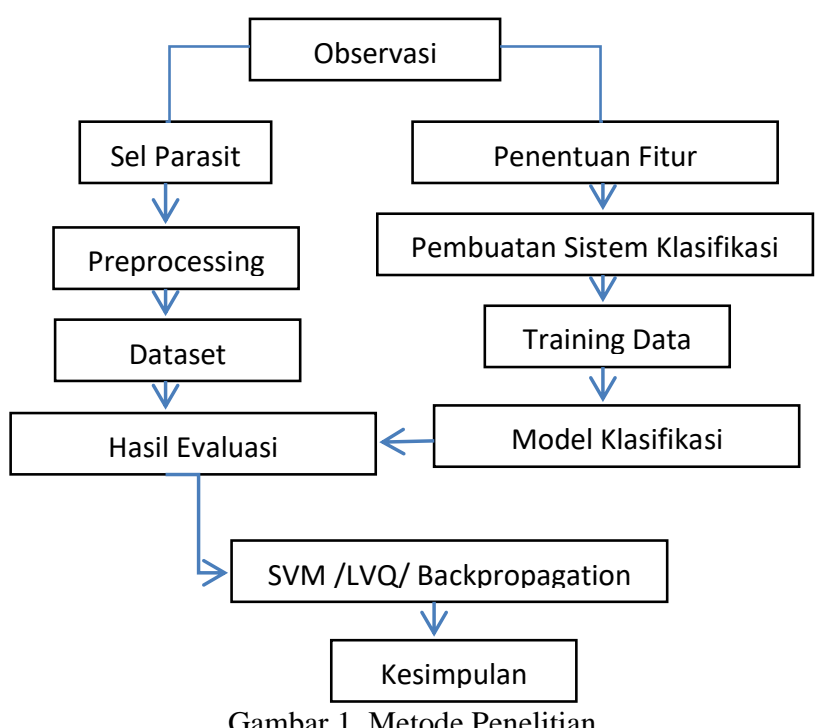

Gambar 1. Metode Penelitian

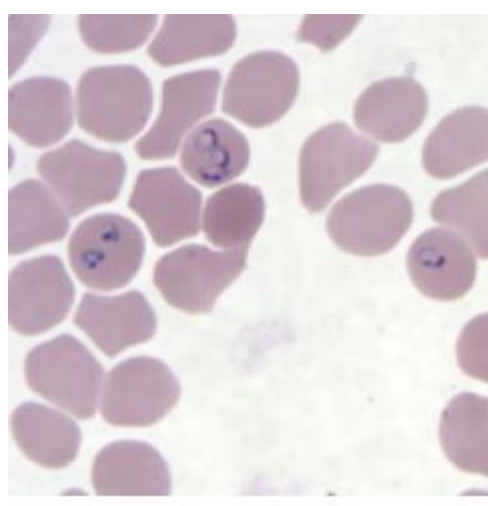

Figure G: Rings of $P$. falciparum in a thin blood smear.

Gambar 2. Data yang sudah dilabeling

Hasil proses contrast stretching digunakan dalam proses segmentasi pada tahap ini digunakan metode otsu untuk memisahkan backround dan mengambil citra parasite yang akan diukur berdasarkan ciri bentuk menggunakan morphology.

Morphologi digunakan untuk pembatas objek agar dapat dilakukan perhitungan seperti perimeter dan area, yang ditunjukkan pada persamaan (1) dan (2) [19].

$$
\text { Area }=\Sigma_{x} \Sigma_{y} f(x, y)
$$

Perimeter $=\Sigma_{x} \Sigma_{y} f(x, y), x, y \in$ Boundary region 
Setelah nilai area dan perimeter diperoleh, selanjutnya dilakukan proses untuk mencari nilai ciri fitur dengan perhitungan statistic orde kedua yaitu matriks kookurensi. Hasil dilakukan dengan menghitung probabilitas hubungan ketetanggaan antara dua pixel terhadap jarak dengan berorientasi pada sudut tertentu. Seperti ditunjukkan pada Gambar 3

\begin{tabular}{|c|c|c|c|c|c|c|c|}
\hline 0 & 0 & 1 & 0 & 0 & 0 & 0 & 0 \\
\hline 0 & 0 & 1 & 1 & 1 & 1 & 0 & 0 \\
\hline 0 & 1 & 1 & 1 & 1 & 1 & 0 & 0 \\
\hline 1 & 1 & 0 & 0 & 1 & 1 & 0 & 0 \\
\hline 0 & 1 & 0 & 0 & 1 & 1 & 1 & 0 \\
\hline 0 & 1 & 1 & 1 & 0 & 1 & 1 & 0 \\
\hline 0 & 0 & 0 & 0 & 1 & 1 & 0 & 0 \\
\hline 0 & 0 & 0 & 0 & 1 & 0 & 0 & 0 \\
\hline
\end{tabular}

Gambar 3. Citra parasite malaria yang diresize ke [8 $\mathrm{x}$ 8]

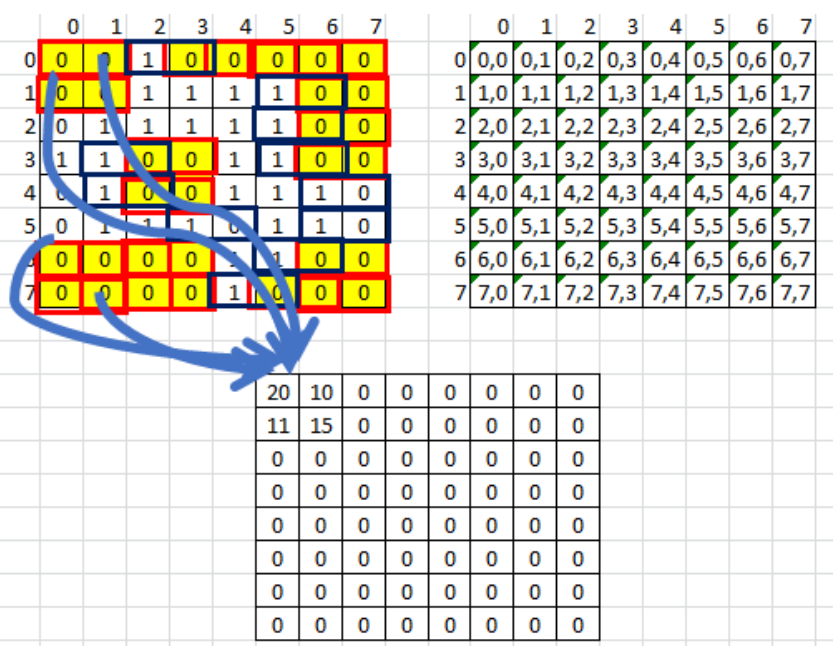

Gambar 4. Penentuan awal matriks GLCM

\begin{tabular}{|c|c|c|c|c|c|c|c|}
\hline 0,36 & 0,19 & 0 & 0 & 0 & 0 & 0 & 0 \\
\hline 0,19 & 0,27 & 0 & 0 & 0 & 0 & 0 & 0 \\
\hline 0 & 0 & 0 & 0 & 0 & 0 & 0 & 0 \\
\hline 0 & 0 & 0 & 0 & 0 & 0 & 0 & 0 \\
\hline 0 & 0 & 0 & 0 & 0 & 0 & 0 & 0 \\
\hline 0 & 0 & 0 & 0 & 0 & 0 & 0 & 0 \\
\hline 0 & 0 & 0 & 0 & 0 & 0 & 0 & 0 \\
\hline 0 & 0 & 0 & 0 & 0 & 0 & 0 & 0 \\
\hline
\end{tabular}

Gambar 5. Hasil normalisai GLCM

Satu level nilai pixel yang bertetangga dengan satu level nilai pixel lain dijumlahkan dalam jarak (d) dengan berorientasi pada sudut $(\theta)$ tertentu. Seperti ditunjukkan pada Gambar 4. Hasil transpose matrik yang sudah diolah menghasilkan nilai yang dilanjutkan dengan proses normalisasi agar jumlahnya bernilai 1, seperti ditunjukkan pada Gambar 5. Dari sudut empat arah dengan orientasi pada interval sudut yaitu $0^{\circ}, 45^{\circ}, 90^{\circ}$, dan $135^{\circ}$. Nilai fitur dari GLCM yang digunakan dihitung berdasarkan homogenitas, kontras, energy, entropi dan korelasi.

\subsection{Klasifikasi SVM}

Metode klasifikasi berdasarkan teori pembelajaran mesin[19] yang dikenal dengan Support Vector Machines (SVMs). Keunggulan SVMs terletak pada tingkat akurasinya yang tinggi dibandingkan dengan jaringan saraf tiruan, decision tree, dan Bayesian. Hal ini terjadi dikarenakan sebelum digunakan untuk klasifikasi, terlebih dahulu dilakukan pelatihan pada data yang digunakan. Proses pelatihan menggunakan matriks fitur, sebagai input pelatihan. Data diperoleh dari hasil proses ekstraksi fitur. Pada klasifikasi, proses data pelatihan digunakan untuk mencari vektor pendukung dan bias data input. Berikut algoritma pelatihan untuk SVM,

Input: $\mathrm{Z}=$ Hasil proses ekstraksi fitur dalam bentuk matriks. Output: Strain vector sebagai target. Vektor $\mathrm{Y}_{\text {train }}=$ vektor untuk kolom klasifikasi pada kelas pertama, seluruh hasil pada kelas pertama diberikan symbol dengan angka 1, semua gambar apusan darah dari kelas lain dengan angka -1 . Dalam penelitian ini, fungsi kernel Gaussian dengan varians $(\alpha)=1$. Selanjutnya hitung matriks Hessian, misalnya,

Perkalian dari Gaussian untuk $Y_{\text {train }} . Y_{\text {train }}$ merupakan vektor dengan nilai 1 dan -1 . Matriks Hessian berfungsi sebagai variabel input pemrograman kuadratik.

Algoritma pelatihan sebagai berikut:

a. Menentukan input $\left(\mathrm{Z}=\mathrm{X}_{\text {train }}\right)$ dan Target $\left(\mathrm{Y}_{\text {train }}\right)$ untuk pelatihan pada dua kelas.

b. Menghitung Gaussian, ditunjukkan dengan rumus (3)

$$
\mathrm{K}\left(\mathrm{Z}, \mathrm{Z}_{\mathrm{i}}\right)=\exp \left(\frac{-\left|\mathrm{Z}-\mathrm{Z}_{\mathrm{i}}\right|^{2}}{2 \sigma^{2}}\right)
$$

c. Hitung Hessian Matrix ditunjukkan pada rumus (4)

$$
\mathrm{H}=\mathrm{K}\left(\mathrm{Z}, \mathrm{Z}_{\mathrm{i}}\right) * \mathrm{Y} * \mathrm{YT}
$$

d. Tetapkan c dan epsilon. $\mathrm{c}=$ konstanta dalam pengganda Lagrangian dan epsilon (parameter biaya) = nilai batas atas dari a, yang berfungsi untuk mengontrol kesalahan klasifikasi. Penelitian ini menggunakan nilai $\mathrm{c}=100000$ dan epsilon $=1 \mathrm{x}$ $10^{-7}$.

e. Menetapkan vektor e untuk vektor satuan dengan dimensi $=$ dimensi $Y$.

f. Menghitung solusi pemrograman kuadratik ditunjukkan pada persamaan (5).

$$
\mathrm{L}(\alpha)=\frac{1}{2} \alpha^{+} \mathrm{H} \alpha+\mathrm{e}^{\mathrm{T}} \alpha
$$

Untuk pengujian, digunakan data diluar data pelatihan. Hasil proses merupakan nilai indeks dari fungsi nilai maksimum keputusan, menyatakan kelas pengujian. Jika suatu kelas dalam uji klasifikasi cocok dengan kelas data uji, klasifikasi dinyatakan benar. Hasil akhir dari klasifikasi adalah gambar darah yang cocok dengan nilai indeks fungsi keputusan menggunakan SVM satu terhadap semua. Memiliki fitur input data vektor $\mathrm{T}$ untuk data uji (w, $\mathrm{x}, \mathrm{b})$, dan $\mathrm{k}=$ jumlah kelas, data input digunakan untuk proses pengujian. 
Hasil input dalam proses ekstraksi fitur, Proses pengujian adalah sebagai berikut:

a. Menghitung Kernel Gaussian ditunjukkan pada rumus (6)

$$
\mathrm{K}\left(\mathrm{T}, \mathrm{x}_{\mathrm{i}}\right)=\exp \left(\frac{-\left|\mathrm{T}-\mathrm{x}_{\mathrm{i}}\right|^{2}}{2 \sigma^{2}}\right)
$$

b. Penghitungan ditunjukkan pada rumus (7)

$$
f_{i}=K\left(T, x_{i}\right) w_{i}+b_{i}
$$

c. Ulangi langkah 1, 2 untuk $\mathrm{I}=1$ sampai $\mathrm{k}$

d. Menentukan nilai maksimum dari $f_{i}$

e. Kelas i adalah kelas dari $\mathrm{T}$ yang memiliki nilai $f_{i}$ terbesar

\subsection{Klasifikasi LVQ}

Algoritma LVQ ada 2 bagian, sebagai berikut [20]: Algoritma Pelatihan:

a. Menetapkan:

1) Variabel untk bobot awal input ke-j sebagai kelas (cluster) ke-i: $\mathrm{W}_{\mathrm{ij}}$, dengan $\mathrm{i}=1,2, \ldots, \mathrm{k}$; dan $\mathrm{j}=1,2, \ldots, \mathrm{m}$.

2) Max Epoh

3) $\alpha$ (alpha)

4) $\operatorname{Dec} \alpha$

5) $\operatorname{Min} \alpha$

b. Memasukkan :

1) Data input $x_{i j}, i=1,2, . ., n$ dan $j=1,2, \ldots, m$

2) $\quad$ Target $=T_{k}, k=1,2, \ldots, n$

c. Menentapkan kondisi awal : epoh =0;

d. Mengerjakan jika : (epoh $\leq$ MaxEpoh) dan $(\alpha \geq$ $\operatorname{Min} \alpha)$

1) Epoh $=$ epoh +1

2) Untuk $\mathrm{i}=1$ sampai $n$

a) Menentukan $\mathbf{J}$ sehingga $\left\|x_{i}-w_{j}\right\|$ minimum, dengan $\mathrm{j}=1,2, \ldots, \mathrm{K}$

b) Memperbaharui $w_{J}$ : dengan ketentuan: If $\mathrm{T}=\mathrm{C}_{\mathrm{j}}$, then:

$\mathrm{w}_{\mathrm{J}}($ baru $)=\mathrm{w}_{\mathrm{J}}($ lama $)+\alpha\left[\mathrm{x}_{\mathrm{i}}-\mathrm{w}_{\mathrm{J}}(\right.$ lama $\left.)\right]$

c) If $\mathrm{T} \neq C_{j}$, then: $\mathrm{w}_{\mathrm{j}}($ baru $)=w_{J}($ lama $)-\alpha\left[x-w_{J}(\right.$ lama $\left.)\right] ;$

3) Pengurangan laju pelatihan $(\alpha=\alpha-\operatorname{Dec} \alpha *$ $\alpha)$

Dimana dengan parameter $\mathrm{x}, \mathrm{T}, \mathrm{w}_{\mathrm{j}}, \mathrm{C}_{\mathrm{j}},\left\|x-w_{j}\right\|$

$\mathrm{x}=$ vektor input training $\left(\mathrm{x}_{1}, \ldots, \mathrm{x}_{\mathrm{i}}, \ldots, \mathrm{x}_{\mathrm{n}}\right)$

$\mathrm{T}=$ kelas yang benar

$\mathrm{w}_{\mathrm{J}}=$ bobot untuk keluaran ke-j

$$
\left(\mathrm{w}_{1 \mathrm{j}} \ldots, \mathrm{w}_{\mathrm{ij}} \ldots, \mathrm{w}_{\mathrm{nj}}\right)
$$

$\mathrm{C}_{\mathrm{j}}=$ kelas yang ditunjukkan oleh

keluaran ke-j

$\left\|x-w_{j}\right\|=$ jarak antara input training

dan bobot ke-j

Algoritma Pengujian:

a. Input data uji, misalkan: $\mathrm{x}_{\mathrm{ij}}$; dimana

$i=1,2, \ldots, n p ;$ dan $j=1,2, \ldots, m$

b. Untuk $\mathrm{i}=1 \rightarrow$ np kerjakan,

1) Tentukan j hingga $\mathrm{Q} \% \mathrm{X}_{\mathrm{i}}-\mathrm{W}_{\mathrm{j}} \mathrm{Q} \%$ minimum; dengan $\mathrm{j}=1,2, \ldots, \mathrm{K}$

2) $\mathrm{J}=$ kelas $X$

\subsection{Klasifikasi Backpropagation}

Backpropagation disebut algoritma pembelajaran terbimbing yang ada pada jaringan syaraf tiruan, yang biasanya terbentuk dari banyak lapisan yang berfungsi sebagai pengubah bobot yang terhubung pada neuron yang ada pada hidden layer. sebagai contoh pada jaringan saraf tiruan untuk tiga layer terdapat input layer, Hidden Layer, dan output layer. Data latih yang di penelitian yang dilakukan sejumlah 510 untuk input layer, untuk hidden layer, dan keluaran untuk output layer sebanyak dua belas. Terdapat duabelas kelas yang akan diproses pada klasifikasi, dengan duabelas output layer. Ciri yang digunakan sebagai input sebanyak dua puluh dua fitur. 22 fitur dilakukan proses normalisasi, selanjutnya berfungsi untuk input jaringan syaraf tiruan.

Untuk training langkah pertama digunakan Perceptron. Fungsi aktivasi digunakan untuk mengatur bobot. Model feed forward yang digunakan oleh Perceptron artinya sebelum neuron diproses dengan aktivasi terlebih dahulu input dikirim ke sebuah neuron sehingga menghasilkan output.

\section{Hasil dan Pembahasan}

Hasil pengujian menggunakan metode SVM terhadap 510 data citra yang terbagi kedalam 12 kelas. Sebelum dilakukan proses pengujian terlebih dahulu dilakkan pemilihan learning rate yang terbaik menggunakan model $k$-fold cross validation, dengan $\mathrm{k}=1,2,3,4,5$. Dari hasil pengujian menggunakan K-Fold dapat dilihat pada Tabel 1 dan Tabel 2.

Tabel 1. Hasil pengujian klasifikasi SVM dengan linear

\begin{tabular}{clllll}
\hline & $\mathbf{K}=\mathbf{1}$ & $\mathbf{K = \mathbf { 2 }}$ & $\mathbf{K = 3}$ & $\mathbf{K = \mathbf { 4 }}$ & $\mathbf{K = 5}$ \\
\hline Akurasi (\%) & 53.0 & 52.0 & 62.0 & 60.0 & 56.0 \\
Presisi (\%) & 33.0 & 34.4 & 45.3 & 37.8 & 44.0 \\
Sensitifitas (\%) & 38.9 & 37.4 & 45.4 & 44.1 & 43.4 \\
Spesifisitas (\%) & 95.4 & 95.6 & 95.5 & 96.3 & 95.7 \\
\hline
\end{tabular}

Tabel 2. Hasil pengujian klasifikasi SVM dengan RBF

\begin{tabular}{llllll}
\hline & K= 1 & K= 2 & K=3 & K= 4 & K= 5 \\
\hline Akurasi (\%) & 100 & 98.0 & 100 & 100 & 98.0 \\
Presisi (\%) & 100 & 96.2 & 100 & 100 & 97.9 \\
Sensitifitas(\%) & 100 & 99.1 & 100 & 100 & 97.0 \\
Spesifisitas(\%) & 100 & 99.8 & 100 & 100 & 99.8 \\
\hline
\end{tabular}

Hasil pengujian Tabel 1. dan Tabel 2. Menunjukkan SVM dengan kernel linear memberikan akurasi rata-rata $57 \%$ yang tidak memuaskan. Akurasi tertinggi, yaitu $62 \%$, diperoleh ketika $k=3$. Seperti yang ditunjukkan pada Tabel 2, SVM dengan RBF kernel menghasilkan hasil yang jauh lebih baik dengan akurasi rata-rata 99,1\%. Untuk hasil pengujian menggunakan metode Backpropagation, dari hasil pengujian diperoleh hasil seperti yang dapat dilihat pada Tabel 3. 
Tabel 3. Hasil uji menggunakan metode backpropagation

\begin{tabular}{lc}
\hline \multicolumn{1}{c}{ Kelas } & Akurasi \\
\hline parasit dan bukan & $95.7 \%$ \\
Gametosit falcifarum dan bukan & $88.4 \%$ \\
Thropozoit dan bukan & $91.3 \%$ \\
Ring dan bukan & $98.6 \%$ \\
Thropozoit Vivax dan bukan & $100 \%$ \\
Thropozoit Malaria dan bukan & $95.7 \%$ \\
\hline
\end{tabular}

Tabel 4. Hasil Pengujian klasifikasi LVQ

\begin{tabular}{ccccc}
\hline Akurasi(\%) & \multicolumn{2}{c}{ Sensitifitas (\%) } & \multicolumn{2}{c}{ Spesifisitas (\%) } \\
\hline \multirow{7}{*}{77.78} & FR & 0.00 & FR & 82.35 \\
& FS & 40.00 & FS & 80.00 \\
& FT & 100.00 & FT & 76.47 \\
& GF & 100.00 & GF & 73.33 \\
& MG & 40.00 & MG & 80.00 \\
& MR & 20.00 & MR & 81.18 \\
& MS & 100.00 & MS & 74.36 \\
& MT & 50.00 & MT & 79.76 \\
& VG & 100.00 & VG & 75.31 \\
& VR & 100.00 & VR & 74.03 \\
& VS & 50.00 & VS & 79.07 \\
& VT & 100.00 & VT & 76.19 \\
\hline & Rata-rata & 66.67 & Rata-rata & 77.67 \\
\hline
\end{tabular}

Tabel 5. Perbandingan Hasil Pengujian

\begin{tabular}{cccc}
\hline $\begin{array}{c}\text { Metode } \\
\text { Klasifikasi }\end{array}$ & SVM & Backpropagation & LVQ \\
\hline Akurasi & 99,1 & 89,7 & 77,78 \\
Presisi & 98,8 & 88,2 & 83,2 \\
Sensitifitas & 99,2 & 82,9 & 60,5 \\
Spesifisitas & 99,9 & 87,2 & 90,7 \\
\hline
\end{tabular}

Dari Tabel 3 dapat dilihat hasil akurasi bernilai 95\%, untuk gametosit falcifarum dengan akurasi $88,4 \%$, ring dengan akurasi 98,6\%, dan Thropozoit dengan akurasi 91,3\%. Secara keseluruhan, pengujian menggunakan metode backpropagation memiliki akurasi 89,5\%. Pada pengujian dengan LVQ untuk pengujian menggunakan uji K-Fold yang sama dan diperoleh nilai akurasi tertinggi pada 3-fold, learning rate 0,01 , Dec $\alpha$ 0,001 dan Min $\alpha$ 0,0001sebesar 99\% Pada Tabel 4 dapat dilihat hasil pengujian dengan menggunakan metode LVQ.

Dari Tabel 4 hasil pengujian menggunakan LVQ menghasilkan akurasi 77,78\%. Hasil perbandingan pengujian dari SVM, Backpropagation, dan LVQ ditunjukkan pada Tabel 5.

\section{Kesimpulan}

Dari keseluruhan pengujian dapat disimpulkan hasil pengujian menggunakan metode Backpropagation memperoleh hasil $89,7 \%$, menggunakan metode LVQ memperoleh hasil $77,78 \%$, dan metode SVM memperoleh hasil $99,1 \%$. Sehingga pada pengujian dengan 600 data, yang terbagi menjadi 510 data latih dan 90 data uji, dengan pengolah ciri bentuk dan ciri tekstur yang sama, diperoleh hasil metode klasifikasi SVM memiliki tingkat akurasi paling baik.

Untuk saran selanjutnya dapat dilakukan pengujian dengan nilai $\alpha$ yang berbeda, dilanjutkan dengan jumlah data yang berbeda lebih dari 1000 data. Dilakukan juga uji K-Fold untuk klasifikasi. Dari kesemuanya dilakukan perbandingan waktu yang terbaik.

\section{Daftar Pustaka:}

[1] D. G. D. D. O. MALARIA., "Malaria." p. 1882, 1882.

[2] Kementrian Kesehatan RI, "Epidemiologi Malaria di Indonesia," Bul. Jendela Data dan Inf. Kesehat., vol. 1, pp. 1-16, 2011, doi: 2088-270X.

[3] V. S. Neeru Singla, "Deep learning enabled multiwavelength spatial coherence microscope for the classification of malaria-infected stages with limited labelled data size," Opt. Laser Technol., vol. 130, no. March, p. 106335, 2020, doi: 10.1016/j.optlastec.2020.106335.

[4] C. Z. Dongyao Jia, Zhengyi li, "Detection of cervical cancer cells based on strong feature CNN-SVM network," Neurocomputing, 2020, doi: 10.1016/j.neucom.2020.06.006.

[5] J. S. C. Luis Rosado, Jose M. Correia da Costa, Dirk Elias, "A Review of Automatic Malaria Parasites Detection and Segmentation in Microscopic Images," Anti-Infective Agents, vol. 14, no. 1, pp. 11-22, 2016, doi: 10.2174/221135251401160302121107.

[6] E. Rika Rosnelly, Sri Hartati and S. M. Winarko, "Identification of Malaria Disease and Its Stadium Based on Digital Image Processing," J. Theor. Appl. Inf. Technol., vol. 95, no. 3, pp. 700-710, 2017.

[7] L. Rika Rosnelly, Jani Kusanti and S. Wahyuni, "Combination of thresholding and otsu method in increasing results of identification of malaria parasite type in thin blood smear image," Int. J. Psychosoc. Rehabil., vol. 24, no. 4, pp. 3807-3818, 2020, doi: 10.37200/IJPR/V24I4/PR201494.

[8] T. N. C. Margaret A. Philips, Jeremy N. Burrows, ando, Christine Manyando, Van Huijsduijnen, Rob Hooft Van Voorhis, Wesley C. Wells, "Malaria," Nat. Rev. Dis. Prim., vol. 3, 2017, doi: 10.1038/nrdp.2017.50.

[9] C. Mehanian, M. Jaiswal, C. Delahunt, and C. THOMPson, "Computer-Automated Malaria Diagnosis and Quantitation Using Convolutional Neural Networks," Proc. ICCVW, Venice, Italy, pp. 116-125, 2017.

[10] M. Kannaiyan, G. Karthikeyan, and J. G. Thankachi Raghuvaran, "Prediction of specific wear rate for LM25/ZrO2 composites using Levenberg-Marquardt backpropagation algorithm," J. Mater. Res. Technol., vol. 9, no. 1, pp. 530-538, 2020, doi: 10.1016/j.jmrt.2019.10.082.

[11] A. Sapkal and U. V. Kulkarni, "Modified backpropagation with added white Gaussian noise in weighted sum for convergence improvement," Procedia Comput. Sci., vol. 143, pp. 309-316, 2018, doi: 10.1016/j.procs.2018.10.401.

[12] M. Kumar and M. Diwakar, "CT image denoising using locally adaptive shrinkage rule in tetrolet domain," J. King Saud Univ. - Comput. Inf. Sci., vol. 30, no. 1, pp. 41-50, 2018, doi: 10.1016/j.jksuci.2016.03.003.

[13] Y. Wang, J. Liu, R. Li, X. Suo, and E. Lu, "Precipitation forecast of the Wujiang River Basin based on artificial bee colony algorithm and backpropagation neural network," Alexandria Eng. J., vol. 59, no. 3, pp. 1473-1483, 2020, doi: 10.1016/j.aej.2020.04.035.

[14] H. Di, X. Ke, Z. Peng, and Z. Dongdong, "Surface defect classification of steels with a new semi-supervised learning method," Opt. Lasers Eng., vol. 117, no. September 2018, pp. 40-48, 2019, doi: 10.1016/j.optlaseng.2019.01.011. 
[15] X. Liu, K. Chen, T. Wu, D. Weidman, F. Lure, and J. Li, "Use of multimodality imaging and artificial intelligence for diagnosis and prognosis of early stages of Alzheimer's disease," Transl. Res., vol. 194, pp. 56-67, 2018, doi: 10.1016/j.trsl.2018.01.001.

[16] B. Mokbel, B. Paassen, F. M. Schleif, and B. Hammer, "Metric learning for sequences in relational LVQ," Neurocomputing, vol. 169, pp. 306-322, 2015, doi: 10.1016/j.neucom.2014.11.082.

[17] B. B. Traore, B. Kamsu-Foguem, and F. Tangara, "Deep convolution neural network for image recognition," Ecol.
Inform., vol. 48, pp. 257-268, 2018, doi: 10.1016/j.ecoinf.2018.10.002.

[18] S. Robertson, H. Azizpour, K. Smith, and J. Hartman, "Digital image analysis in breast pathology-from image processing techniques to artificial intelligence," Transl. Res., vol. 194, pp. 19-35, 2018, doi: 10.1016/j.trsl.2017.10.010.

[19] B. R. Gonzalez, R. C., Woods, R. E., \& Masters, Digital Image Processing Using Matlab - Gonzalez Woods \& Eddins. 2013.

[20] L. Fausett, Fundamentals Of Neural Network Architectures, Algorithms, and Applications, vol. 116, no. 0. 1994. 